\title{
CRÍTICA Y SÁTIRA SOCIAL EN LA POESÍA DE LUIS FELIPE VIVANCO: PROSAS PROPICIAS (1976)
}

\author{
ANDRÉS ROMARÍS PAIS \\ I.E.S. Antonio Fraguas \\ Santiago de Compostela
}

\section{RESUMEN}

La mayor parte de la obra poética de Luis Felipe Vivanco se caracteriza por su reflexión intimista sobre una realidad hondamente personal centrada en lo cotidiano, lo familiar, lo religioso y la naturaleza, con una estética y estilo que el propio poeta denominó «realismo intimista trascendental». Sin embargo, en Prosas propicias, su última obra publicada póstumamente, reflexiona también sobre la realidad social y política de los últimos años de la dictadura franquista, lo que sin duda es algo novedoso en su poesía. El estudio de este nuevo ámbito temático es precisamente el objetivo de este artículo.

Palabras clave: Luis Felipe Vivanco, Prosas propicias, poesía posguerra, Generación del 36, crítica social, sátira.

\section{ABSTRACT}

Most of the poetry written by Luis Felipe Vivanco is characterised by its intimate reflection on a deeply personal reality focused on daily, familiar, religious and nature related issues. The aesthetics and style of his work were defined by the poet himself as «transcendental innermost realism». Despite this, Prosas propicias, his last work — posthumously published-contemplates the social and political reality in the last years of Franco's dictatorship. This is a novelty in Vivanco's poetry. The study of his new field is precisely the objective of this article.

Key words: Luis Felipe Vivanco, Prosas propicias, post-war poetry, the Generation of 1936, social criticism, satire.

1. En la historia de la literatura la obra global de un autor se tiende a simplificar y a constreñir a una serie de rasgos que se convierten en canónicos y, a la larga, en tópicos que serán reiterados en sucesivos estudios de carácter general. Esta simplificación no presupone necesariamente una distorsión del sentido y alcance de la obra de ese autor, pero, en cualquier caso, casi siempre hay aspectos o ramificaciones de la misma que se obvian y tienden a olvidarse.

De la poesía de Luis Felipe Vivanco (1907-1975) se dice, por ejemplo, en una antología sobre la Generación del 36 (en la que la historiografía 
literaria lo suele incluir) que «... es una ascensión implacable hacia la perfección, la de la belleza literaria y la del propio poeta, cuya mirada, cada vez más penetrante, hace que todas las cosas se vuelvan signo de presencia divina. El amor a la naturaleza, al campo, en concreto, a la intimidad de lo cotidiano en el hogar, a la esposa, a los hijos, así como su contrapartida: el desprecio, el repudio de cuanto no es verdadero ni auténtico, ha encontrado en Vivanco una expresión suma, inolvidable» ${ }^{1}$. Este es el cliché habitual que se repite sobre su poesía, el cual, a pesar de su simplificación, no es desacertado. Al leer los largos y ampulosos versículos del desbordado discurso neorromántico de sus dos primeras obras publicadas - Cantos de primavera (1936) y Tiempo de dolor (1940)—, el lector descubre una temática y tono en consonancia con la declaración poética inicial que aparece en la primera de las obras señaladas: «canto y escribo mis versos como hombre, como cristiano, como creyente y como enamorado». Su obra poética posterior, la escrita entre 1945-1965 - Los caminos, Continuación de la vida, El descampado, Lugares vividos- se aquieta y depura en la línea estética de un revalorizado Antonio Machado, y en ella lo cotidiano, lo familiar, lo religioso y la naturaleza delimitan el ámbito de reflexión intimista del yo poético ${ }^{2}$. El propio Vivanco caracterizó esta etapa poética suya como de «realismo intimista trascendente». En definitiva, aunque evolucione en su estilo, el talante religioso y ético al que Vivanco subordina su obra no ha variado, como en su momento ya observó José M. ${ }^{a}$ Valverde: «idéntica en su razón última, pero diametralmente oscilante en las actitudes expresivas concretas» ${ }^{3}$. Ahora bien, en tres poemarios de Vivanco -Memoria de la plata (1958), Lecciones para el hijo (1961), Prosas propicias (1976) — hay aspectos temáticos y/o estéticos que no responden a los parámetros de la anterior caracterización. Así, por ejemplo, la temática y crítica social.

2. La faceta de Luis Felipe Vivanco como poeta crítico y satírico suele ser desconocida, en principio por dos razones. En primer lugar, generalmente se tiene un conocimiento parcial o indirecto de su obra a partir de antologías o ensayos sobre la poesía de posguerra; en tal caso, ha quedado

${ }^{1}$ Vid. Francisco PÉREZ GutiÉRreZ, La generación de 1936, Madrid, Taurus, 1976, pp. 191-192.

${ }^{2}$ El profesor Fernández Roca considera que los cuatro poemarios conforman un misma etapa, pero a su vez divisible en otras cuatro que etiqueta de la siguiente forma: a) el recogimiento en lo cotidiano (Los caminos); b) poesía temporal y familiar (Continuación de la vida); c) ascetismo paisajístico (El descampado) y d) el paisaje animado ( $\mathrm{Lu}$ gares vividos). Vid. José Ángel FERNÁNDEZ RoCA, «La palabra vivida. Aproximación a Luis Felipe Vivanco y su poesía», en Luis Felipe Vivanco, Obras. Poesía 1, ed. de Pilar YAGÜE y José Ángel FernándeZ RocA, Madrid, Trotta, 2001, pp. 49-50.

3 José M. ${ }^{a}$ VALVERDE, «La humildad de ser poeta», en Estudios sobre la palabra poética, Madrid, Rialp, $2^{\text {a }}$ ed., 1958, pp. 196-197. 
fijada en la expectativa del lector el realismo intimista trascendental que delimita y explica el grueso de su producción poética. En segundo lugar, porque su poesía crítica se reduce prácticamente a su última obra, Prosas propicias, que se publicará inconclusa al año siguiente de su muerte, aunque algunos de sus poemas ya habían ido apareciendo en revistas desde $1971^{4}$. Pero, aparte de desconocida, para muchos puede resultar incluso sorprendente su imagen de poeta crítico, si anticipamos que el blanco de su denuncia y sátira es la dictadura franquista.

En efecto, hay circunstancias que han condicionado la percepción de su obra y la de otros de sus compañeros de grupo literario. Ya comenzada la guerra civil, Luis Felipe Vivanco se incorporó a un significativo grupo de jóvenes intelectuales integrados en la Falange. Todos ellos —entre otros, Dionisio Ridruejo, Pedro Laín Entralgo, Luis Rosales, Gonzalo Torrente Ballester, los hermanos Panero y el no tan joven Eugenio D'Ors- tuvieron una importante presencia en la vida cultural que el bando nacional intentó revitalizar desde comienzos de la contienda. Durante la misma, como sus compañeros y amigos, colaborará en distintas revistas del bando sublevado - Jerarquía, Vértice-, en varias de sus publicaciones colectivas - Los versos del combatiente, Corona de sonetos a José Antonio-, y elaborará y prologará el tomo I de la antología Poesía heroica del imperio para la recién creada Editora Nacional. Finalizada la guerra, Vivanco colaboró en Escorial, la célebre revista fundada en 1940 y cauce que aglutinó a un determinado grupo de poetas - Ridruejo, Rosales, Vivanco, Leopoldo Panero- de la cuestionada Generación literaria del 36. De esta publicación se ha destacado su talante aperturista y tolerante, así como su propósito de integración y recuperación cultural de la otra España. Sin embargo, no es menos cierto - y así nos lo recuerda José Carlos Mainer-que en sus dogmáticos editoriales sigue latente una idea apodíctica, sacramental y nacionalista de la cultura propia del Régimen que la auspiciós. Algunos de

\footnotetext{
${ }^{4}$ Sólo en su primera y juvenil obra - Memoria de la plata_, compuesta entre 19271930 y reescrita en parte para su tardía primera edición de 1958, podemos encontrar algunos versos irónicos alusivos a la vacuidad espiritual, convenciones morales y religiosas, e hipocresía de la sociedad, como vemos, por ejemplo, en los poemas «Conversación entre barrancas», «Plática sobre la elección de estado (fisiología e higiene)», o «Enemigo del alma: carne» (vid. Andrés RomARís PAIs, «Memoria de la plata, de Luis Felipe Vivanco, en el contexto del vanguardismo español», Letras de Deusto, vol. 32, n. ${ }^{\circ}$ 96, 2002, pp. 91-124.

5 Vid. José Carlos Mainer, «La revista Escorial en la vida literaria de su tiempo (1941-1950)», en Literatura y pequeña burguesía en España, Madrid, Cuadernos para el Diálogo, 1972, pp. 241-262. Manuel Contreras incide en la misma objeción; tras apuntar que la revista fue «uno de los más empeñados vehículos ideológicos y culturales de los que fletó el nuevo Estado surgido de la guerra», cree que —en su origen y a lo largo de su primer lustro de vida - su intención no fue sinceramente aperturista y que su propósito fue el de la propaganda dirigida a los sectores intelectuales que con-
} 
los artículos teóricos - $\mathrm{y}$ en especial «El arte humano» y «El poeta de Adelfos»- que Vivanco publicó en los dos primeros años de Escorial contienen según Sultana Wahnón las exigencias básicas de la norma estética escorialista, resultado de la simbiosis entre la estética fascista de Giménez Caballero y el modelo poético clasicista (o garcilasista) que - ya dentro de la órbita del falangismo- había elaborado y publicado Luis Rosales en los preliminares de la guerra civil ${ }^{6}$.

Ahora bien, enseguida hay un progresivo desacuerdo y consiguiente distanciamiento de casi todos los componentes de este grupo con la Dictadura franquista, sobre todo a partir de 1945, con la emblemática figura de Dionisio Ridruejo al frente de todos ellos? ${ }^{7}$ En una carta de Vivanco de

venía captar y asimilar por su potencial capacidad para cubrir las necesidades ideológicas y culturales del nuevo Estado» (vid. Manuel CONTRERAS, «Ideología y cultura: la revista Escorial (1940-1950), en AAVV, Las fuentes ideológicas de un régimen (España 1939-1945), Zaragoza, Libros Pórtico, 1978, pp. 55-80). En la misma línea Sultana Wahnón opina que sus fundadores pretendían llevar a la práctica las normas culturales y artísticas expuestas en Arte y estado (1935), de Giménez Caballero, el más importante ideólogo del fascismo español. Por ello duda de su liberalismo y aperturismo, por lo menos en sus dos primeros años de existencia — con Dionisio Ridruejo en su dirección-; es más, considera que su pretendida voluntad integradora puede explicarse como un elemento más de la estrategia cultural fascista. Afirma taxativamente: «Con Serrano Súñer la Falange tuvo todo el control de la propaganda del Estado y, dentro del aparato de propaganda totalitaria de Ridruejo, Escorial fue un elemento más» - p. 191- (Vid. Sultana Whanón, Estética y crítica literarias en España (1940-1950), Universidad de Granada, 1988 (véase en especial su Capítulo III, pp. 169-336). Desde otra perspectiva, Gonzalo Torrente Ballester —en un artículo homenaje a Ridruejo- recuerda cómo varios jóvenes escritores siguieron expectantes el sinuoso proceso para la autorización de la futura revista «de cuyas esperadas características algunas comportaban más servidumbres que libertades; pero, en aquellos tiempos, ni podía esperarse otra cosa, ni era políticamente posible». Puntualiza, además, que aunque muchas de sus páginas y autores «aparecen contagiadas de imperialitis», nadie de los que escribieron en Escorial en sus dos primeros años lo hicieron coaccionados ideológicamente — «la moral de «colaboracionismo» vino después»— ya que «a nadie se exigió, ni se sugirió siquiera, la más mínima palabra de adhesión a las ideas que la revista necesariamente había de sustentar o a las personas que las representaba». Recuerda, asimismo, la respetuosa convivencia en sus páginas - a lo largo de los dos años de dirección de Ridruejo- de republicanos y falangistas, germanófilos, víctimas de la represión de izquierdas y víctimas de las de derechas (Vid. Gonzalo TORRENTE BALLESTER, «Escorial en el recuerdo», en AAVV, Dionisio Ridruejo, de la Falange a la oposición, Madrid, Taurus, 1976, pp. 61-68.

${ }^{6}$ Se refiere al artículo «La figuración y la voluntad de morir en la poesía española», Cruz y Raya, n. ${ }^{\circ}$ 38, Mayo 1936, pp. 67-101. Los artículos de Vivanco son analizados por Sultana Wahnón en las pp. 193-221 y 247-269.

${ }^{7}$ Tal vez porque sólo se sintieron cercanos $-\mathrm{y}$ en el caso de Vivanco por razones aleatorias - a lo que Ridruejo ha llamado «Falange hipotética», aquella que «estuvo constituida por el conjunto de subjetividades de buena voluntad que creían estar participando en un movimiento de regeneración del país, tanto en el orden de su potenciación nacional como en el orden de su reforma social.... La «Falange real» fue el instrumento concreto que sirvió a una guerra civil y fue utilizado después como base de un poder 
1970 dirigida a Victorino Rodríguez — autor de una tesis doctoral sobre el poeta- aquél dice haber dejado de colaborar con el Régimen en 1945, pero José Ángel Fernández Roca —a la vez que señala los acontecimientos que pudieron influir en su cambio de postura (destierro de Ridruejo, matrimonio con una mujer de formación europea y ascendencia judía) - piensa por ciertos datos biográficos que el proceso de alejamiento fue más gradual y que su silenciosa oposición tardaría todavía algunos años más. ${ }^{8}$ En cualquier caso, el grupo quedó marcado y marginado social y literariamente por ambos lados - colaboracionistas para unos, traidores para otros- por lo que no le falta razón a Jaime Siles cuando, al reseñar el Diario de Luis Felipe Vivanco, lo define como un «exiliado interior. Y - si ello es posible- un exiliado, incluso del exilio interior»?

3. Si se lee detenidamente este interesante diario de nuestro poeta, vemos cómo a partir de 1953 empiezan a abundar en sus páginas las críticas referentes a todo el entramado de la Dictadura franquista ${ }^{10}$. Estas son algunas localizadas al azar:

— «18 de julio campesino, con lluvia sobre la yerba, y el color gris oscuro del mar. Sin conmemoraciones ni puñetas. Lo mejor de todo, olvidarlo, como una pesadilla» (1953).

- «Franco, al final de un discurso en Huelva, ha amenazado con la riada de falangistas y requetés. Ya sabemos lo que nos espera (...) Llama «politicastros» a todos los que no piensan sobre España como él. Temo mucho su descomposición de carácter. Debe ser hombre mediocre y cruel, que aún no ha hecho uso de todas sus cualidades malas. En estos días se ven los procesos de los estudiantes» (1956).

esencialmente conservador» (Dionisio RIDRUEJO, «Vida política», en Entre literatura y política, Madrid, Seminarios y Ediciones S. A., 1973, p. 206). En un sentido similar, Laín Entralgo nos habla de su falangismo utópico, de su ideal de conseguir una España "asuntiva y superadora», y se reprocha no haber tenido la gallardía de Ridruejo para haber roto abiertamente con la Falange por su «declinante adscripción al sistema» tras acabar la guerra (Pedro LAín EnTRALGO, Descargo de conciencia (1930-1960), Barcelona, Barral Editores, 1976, pp. 261 y ss.). Por su parte, Mainer apunta que, en sus orígenes, «Falange Española fue la formulación más atractiva y violenta de una rebeldía que se venía larvando de tiempo atrás; en gran medida, fue una vocación juvenil muy pura que, pese a la hipoteca burguesa que la lastró y acabó por disolverla, planteó una primordial protesta contra lo más caduco del derechismo contemporáneo» (José Carlos MAINER, Falange y literatura (Antología), Barcelona, Labor, 1971, p. 13).

${ }^{8}$ Vid. op. cit., p. 30. Esta y otras tres cartas de Vivanco se incluyen en el Apéndice 2 de la tesis doctoral inédita de Victorino Rodríguez, Luis Felipe Vivanco: poeta de la insistencia, University of Southern, California, 1974.

9 Jaime SILES, «El Diario de Luis Felipe Vivanco», Cuadernos Hispanoamericanos, n. ${ }^{\circ}$ 442, Abril 1987, p. 156.

${ }^{10}$ De este diario escrito entre los años 1946 y 1975, y luego mecanografiado por su viuda, su hija Soledad Vivanco Gefaell publicó varios años después una selección de sus páginas (Luis Felipe Vivanco, Diario 1946-1975, Madrid, Taurus, 1983). 
— « Premio Nobel de Literatura para Juan Ramón! (...) Viene su retrato en la primera página del $A B C$. Premio Nobel para España. Sí, sí, pero precisando: para un héroe español del exilio. También Federico era España y le fusilamos. También Antonio Machado era español y le dejamos morir, entre todos, en Collioure» (1956).

— «(iQué locutores del desfile! Qué vergüenza. Dicen que algún año destituyeron a alguno, por no poner demasiado entusiasmo. Y éste, desde luego, no quiere ser destituido. ¿Qué admiración ante los tanques y cañones!)» (1957).

- «Escrito de los intelectuales a Fraga sobre lo abusos de la G. C. en Asturias. La firma de Pepe es una de las primeras y le escogen como cabeza de turco. Respuesta indigna de Fraga, a sabiendas de que miente, y ataques contra Pepe -en primer lugar- y contra «los intelectuales» en todos los periódicos. Y mientras, ya está funcionando otra vez el Concilio. Ya están los padres españoles pasando por el aro. Pero aquí se avecinan tiempos vergonzosos» (1963).

- «En cuanto sucede algo de este tipo, se ve el bajo nivel humano a que han llegado la sociedad española y los medios de información. El Ministerio de Información se cubre de gloria no-informando, y el Pardo aprovecha la ocasión para demostrar una vez más el desprecio que le merecemos treinta millones de españoles. ;Que nos enteremos de las cosas por el extranjero, cuyos periódicos no dejan entrar!» (1965).

— «Empiezan los disturbios estudiantiles. En realidad, la juventud ha quedado eliminada, después de las últimas leyes, del futuro de España. El futuro, ese futuro, es ella, pero oficialmente no le pertenece. Tiene que dejar de ser juventud y convertirse en lealtad al régimen. Ya estaban eliminadas la «clase» obrera y la «clase» intelectual. Ya estábamos eliminados toda clase de escritores. Y no digamos los partidos políticos. Franco quiere organizarse el futuro a su manera y lo va a conseguir, frente a Europa, la Iglesia Católica y el mundo entero» $(1967)^{11}$

Ahora bien, a lo largo de casi todos esos años Vivanco no se interesó en hacer poesía de esta realidad histórico-social que particularmente deploraba. Huyendo de esa «realidad convencional disminuida», de la que se lamenta en su diario, había buscado refugio en su personal «realidad del

\footnotetext{
${ }^{11}$ Incluso -en una entrada de 1961- Vivanco esboza un proyecto de farsa antifranquista: «Una comedia aristofanesca sobre Franco y el régimen español. Un americano que viene a España con su hijo, para educarle en nuestros principios políticos, que van a ser los del futuro. Franco en un cesto, como Sócrates, y coro de las Femeninas con sus danzas y bailes y sus asignaturas de Hogar. ¿Qué gran farsa! El americano, descontento de su democracia, que quiere hacer a su hijo demócrata orgánico. Pero el hijo se le vuelve a América y entonces se hace él. Y resulta fascista (Op. cit., p. 168).
} 
mundo», una realidad plena que lo religaba a Dios a partir del instante vivido en familia y en contacto con la naturaleza. En 1946, recién iniciado su diario, confesaba su «Incapacidad para interesarme de veras o emocionarme, ni poética ni humanamente, con las cosas públicas, es decir, con la política. Sentimientos íntimos como refugio contra el mundo. Éste ha sido siempre el núcleo temático de mis poemas» ${ }^{12}$. Tal incapacidad y desinterés seguirá vigente en el plano creativo durante las décadas de los cincuenta y sesenta, si bien humanamente es obvio que ha habido un cambio en su actitud crítica, como lo muestran las reflexiones de su diario que acabamos de reproducir. Quizás lo que nos resulta paradójico de tal desinterés es que se produzca precisamente cuando el compromiso social estaba vigente en todos los géneros de nuestra literatura. Sucedía, sin embargo, que Vivanco se sentía muy lejos de los presupuestos estéticos de una poesía social que artísticamente menospreciaba ${ }^{13}$.

Sólo a partir de 1971 o 1972 —es decir, coincidiendo con el inicio de gestación de Prosas propicias - Vivanco se decide a incorporar esta realidad histórico-social a su poesía, con un ímpetu y mordacidad crítica que no deja de sorprender ${ }^{14}$. Con razón Florencio Martínez, al leer algunos de los poemas anticipados en una breve selección elaborada por José M. ${ }^{a}$ Valverde, apuntaba que la antología «desmonta los lugares comunes en torno a su conformismo social» ${ }^{15}$. Los factores que explican el cambio operado en nuestro poeta para dar cabida en su obra a una temática e intención crítica, hasta ahora rechazada, son varios: por un lado, la progresiva implicación política en la lucha contra la Dictadura de amigos íntimos y familiares -incluidos sus hijos-, las inevitables represalias del Régimen que

${ }^{12}$ Y apostillaba: «El mundo de Los caminos es un mundo aparte del mundo profesional y social, y no digamos de los acontecimientos políticos de actualidad. Cada vez siento más a mi mujer y a mi hija como formando parte de mi vida. Cada vez siento más esta capacidad poética y religiosa absorbente de reclusión en lo privado, como lo único que merece la pena, es decir, lo único transparente de veras al Señor» (Ibidem, p. 18).

${ }^{13}$ El realismo social era incompatible con su «realismo intimista trascendental»; de ahí los varios juicios peyorativos sobre la poesía social que encontramos en su diario. En 1951 anota: «iEste mundo no es un valle de lágrimas! Tiene razón Keats, es un valle de ensueños, y de creación activa, y de afirmación contra la mediocridad. Hay que elevarse sin descanso. ¡Mecachis en el arte social! ¡Hay que ser uno, uno!» (...) «Hay que ser poeta. Pero no como G., ni como C., ni como ... más vale no seguir. Qué a disgusto frente a toda la poesía estreñidita actual. ¿Qué tiene que ver todo esto con la poesía?» (p. 61). En 1960 escribe: «Dejar a otros la poesía social, el periodismo, lo falso en la palabra. Seguir en la línea de Leopoldo. En una lírica temporal, y personal, de palabra intensa suficiente» (p. 139); y en ese mismo año añade: «La vuelta a Rilke y a la poesía del misterio y del estremecimiento. Nada de poesía social» (p. 156)

${ }^{14}$ Luis Felipe Vivanco, Prosas propicias, Barcelona, Plaza \& Janés, 1976.

15 Vid. Florencio Martínez Ruiz, «Poesía. Antología poética, por Luis Felipe Vivanco», Blanco y Negro, n. ${ }^{\circ} 3367,13$ Noviembre 1976, p. 68. 
éstos sufren —detenciones, exilios, cárcel...-, un cierto sentimiento de culpabilidad por no implicarse más en su oposición a la Dictadura...; por otro, la crisis de índole creativa y también personal — muerte de su madre, achaques de salud, una cierta fragilidad en su fe- que sufre el poeta por esos años. Todo ello origina que el ámbito intimista en el que se había refugiado literariamente se desmorone y que, paralelamente, su discurso poético anterior, sobrio y contenido, se sienta como insuficiente para expresar su nueva realidad vital. Además de esto, cuando empieza a escribir Prosas propicias, ya completamente desfasado el realismo social, Vivanco se siente estéticamente más cercano al tratamiento que la llamada «Generación del 50» daba al tema social; una muestra de ello son las «prosas» que compone dedicadas a Félix Grande, por Blanco spirituals, y a Mariano Roldán por la totalidad de su obra ${ }^{16}$.

La renovación formal de Prosas propicias salta a la vista. Son poemas en prosa organizados en párrafos - aunque varios críticos se refieren a ellos como «versículos muy largos, que se mueven en la frontera misma del verso y la prosa $»^{17}$, formados a su vez por varios enunciados en los que se prescinde de los signos de puntuación básicos — punto, punto y coma, coma- que son sustituidos por dobles o triples espaciados, facilitando en cierta manera una lectura que en principio se nos presenta anárquica y dificultosa. Además, tales párrafos se organizan a modo de estrofas, siempre y cuando Vivanco los individualiza no sólo con el clásico espaciado en blanco sino también con el recurso tipográfico de la llamada sangría francesa (sangrado de todas las líneas, excepto la primera de cada párrafo). Asimismo es renovador y sorprendente su estilo: por una parte, por sus abundantes y complejas imágenes de fundamento irreal y otros recursos que nos recuerdan el discurso surrealista de Memoria de la plata; por otra, el peculiar ritmo de pensamiento que rige su escritura, sólo sujeta a la tensión emotiva del sujeto poético.

4. En cuanto a la novedad de la temática social, esta ya se observa en la primera parte — la titulada «Prosas líricas»— de las tres en que se divide la edición póstuma de Prosas propicias. Si bien en esta sección inicial se ahonda en el mundo interior y personal del sujeto poético, observamos cómo breves reflexiones críticas afloran ya en los textos más

${ }^{16}$ En Blanco Spirituals (1967) de Félix Grande es evidente la temática social y la actitud crítica, pero el enfoque y la forma expresiva cuidada, rupturista e innovadora ya no tiene nada que ver con la estética de la poesía social. Lo mismo puede decirse de la poesía de Mariano Roldán cuyo modo estético ha sido definido por algún crítico como «realismo en meditación».

17 Vid. José Luis LóPeZ Aranguren, «Conclusión de vida», en El oficio de intelectual y la crítica de la crítica [1979], cito por Obras completas, vol. 5, Madrid, Trotta, 1996, p. 355. 
intimistas: quejas contra la censura — «No hay falda ni breviario sin censura»(Languidez)—; ironías alusivas a las clases pudientes y dirigentes - «lagunas cinegéticas para humillar los plomos del disparo que abre en el aire plácido la bilis subterránea adinerada de cada figurín o títere valioso o contagioso» (Ruidera) -; denuncia del consumismo y el deterioro ecológico — «Lagunas a trasmano para vivir de sobra y para estar de más en el pérfido ensayo de consumo integral que nos reúne a todos por riguroso orden de edad que es el mismo que seca nuestros tréboles...» (Ruidera)—; crítica de la ambición política - «Camino entre retablos de ambición que me dejan detrás de su política de poder a poder y hombro con hombro» (Infantes)—. En otra prosa lírica —la titulada «Epitalamio»— Vivanco, al aludir a la ascendencia de su esposa, recuerda la sempiterna persecución del pueblo judío y su último genocidio: «Tu apellido Guefél lleva en su pasaporte muchos cauces y siglos nacionales de acoso y de violencia», «Tu segundo apellido te acerca a un cumplimiento de huesos calcinados y escena de pretorio». En muchos de los párrafos estróficos de «Zodíaco», y tras el aparentemente superficial juego retórico que se despliega en la caracterización de los doce signos astrales, hay una solapada y punzante crítica dirigida a los distintos sectores sociales:

Tentáculos de Cáncer arriostran los bolsillos más especuladores mientras ¡cuidado amigo con el soplo caliente de la orina que canta a la intemperie expuesto a una falsa pobreza franciscana que no le corresponde!

Procedente de Leo descubre el emisario sus leyes indecentes de procreación sin fallas de optimismo y rezuma tartufo a trompicones la más negra perfidia con botones dorados de uniforme que administra muy mal la crueldad de sus rezos

$(\ldots \ldots \ldots \ldots \ldots . . .$.

Los que llegan al mundo al par de la resaca del corazón de Escorpio gozan de una hinchazón inmerecida de aire insubordinado y preguntan sin fin por todos los conceptos que les hacen chocar varias veces seguidas contra el mismo acusica disfrazado

Los vástagos del noble y discutible Sagitario relumbran a la orilla de sus torpes propinas royendo fantasmales el vientre de una soga podrida y apta para entrenar sus pecados de ociosos directivos y su carga invisible de gusanos

Un cierto sentimiento de culpa por implicarse tardíamente en su oposición a la dictadura lo vemos en este enunciado poético de «Infantes» (poema suscitado por la visita a Villanueva de los Infantes, la villa en que murió Quevedo): «Camino como un huésped mutilado celebrado y equívoco por dentro pero sucio por fuera de tanta retirada y oposición tardía...». Descargo de conciencia aún más hiriente al ser consciente de que la dictadura aún se mantiene sólida, como se sugiere en el siguiente párrafo estrófico 
del mismo poema con su velada alusión a los «muros de la patria mía...» del conocido soneto quevediano: «Camino retrasado con el sepulcro dentro sólo para ir tirando gris y ayuno entre sólidas murallas que mantienen intacto su prestigio de hisopo natural casulla artificial y montería Mantienen bien cerrada su bravata ancestral su condición de embozo consagrado».

Aparte de estas reflexiones más o menos dispersas, dos poemas de la sección «Prosas líricas» son críticos en su totalidad. En el titulado «Calatrava», la contemplación en la comarca ciudadrealeña de las ruinas de la fortaleza-iglesia de la orden militar-religiosa del mismo nombre suscita en el yo poético una reflexión moral y crítica. Recordemos su comienzo: «Lo mejor y lo peor de estas murallas rodeadas de miradas agrestes cóncavas y vacantes es que hayan muerto todos ¿con las armas en la mano y la cruz deformada sobre el pecho? La cruz de Calatrava para matar infieles para lavar con sangre los agravios...». En sus dos extensos párrafos-estrofa se reprueba el maridaje guerra-religión y, por el contrario, se aboga por un sentido evangélico de la religión fundamentado en la sencillez, la fraternidad y la no violencia: «Lo más alto y lo más bajo que desciende a las mazmorras y sube a las estrellas primerizas de un lubricán sagrado es la cruz que no sabe que proviene de la sangre final de un cristo-reo con los brazos en cruz Haz una cruz sencilla con los brazos en cruz con los brazos hermanos en caridad que niega las distancias Haz una cruz sencilla de hombre a hombre de mujer a mujer o de hombre a mujer de unos a otros y hasta de padres a hijos sin blasones ni herencia aclimatada». En su enunciado final la crítica apunta directamente a la «cruzada» de la Guerra civil y los, en aquel tiempo, tan ponderados veinticinco años de paz de la dictadura: «Lo más alto y más bajo es que hayan muerto todos y hayamos heredado sus gloriosas murallas donde tal vez no han muerto y siguen vigilando nuestra paz imposible nuestras manos honradas e incruentas con su honor pordiosero de fantasmas que lucen sobre el pecho la cruz de Calatrava». Paz imposible en una España escindida en vencedores y vencidos, a la que también se alude en «Las nueve musas», en la estrofa dedicada a la protectora de la Historia: «Clío viste de luto su mezcla utilitaria de fuegos como arañas y levanta los brazos imponiendo silencio de vencidos a costa de una púdica playa encinta de nubes».

Más directo en su crítica es el poema «Recluta». Formalmente es una extensa serie de enunciados paralelísticos, agrupados en cuatro grupos estróficos, en los que se denuncia la adulteración de la verdadera función que deberían cumplir ciertas instituciones y actividades. Las denuncias más cáusticas apuntan a la institución militar (que abarca todo su primer párrafo estrófico y concluye con un taxativo «No se hizo el pueblo para el ejército sino el ejército para el pueblo»), a la política («No se hizo el pueblo para el que gobierna sino el que gobierna para el pueblo / No se hizo el que trabaja para el sindicado sino el sindicato para el que trabaja»), y a la 
Iglesia («No se hizo el seglar para el cura sino el cura para el seglar»), para concluir con un enunciado que condensa todo el mensaje humanista y social del poema: «En resumidas cuentas se hizo el hermano para el hermano y se hizo el hombre para el hombre».

5. A diferencia de la sección «Prosas líricas», la temática e intención de los poemas de la segunda parte de Prosas propicias es crítica en su totalidad, como se deduce de su título: «Sátira». Hodgart Matthew definía el subgénero de la sátira como un modo de considerar la vida, que se concretaba en una postura mental de crítica y hostilidad ante la irritación causada por el vicio y la estupidez humana. En la misma línea, tanto C. George Peale como Linda Hutcheon consideran que uno de los parámetros básicos para analizar la naturaleza de la sátira es su actitud e intención. Para esta última, además, la intencionalidad es básica para diferenciar entre sátira, ironía y parodia. Tanto la censura moral y social $-\mathrm{y}$ con el componente indispensable del humor - como la intención correctora son aspectos básicos atribuidos a la sátira desde sus orígenes latinos. En este sentido, la profesora Hutcheon define el «ethos» satírico (entendiendo como «ethos» el sentimiento que el emisor busca comunicar al receptor) como esencialmente corrector: corregir vicios y necedades del comportamiento humano ridiculizándolas. Ahora bien, muchos críticos — Frye y Peale, entre ellos- piensan que la finalidad de la sátira no es necesariamente moral ni correctora o reformadora, sino esencialmente ética ${ }^{18}$. A este respecto, Peale matiza que su propósito y actuación «...no pasa de ser la nueva conciencia y comprensión del objeto satirizado; pero, por modesta que parezca, esta actuación cognoscitiva es ética en su fondo, porque con todo cambio intelectivo se comprende una alteración en el ethos total del sujeto inteligente» ${ }^{19}$. Creo que sólo en este sentido se puede entender la pretensión satírica de Vivanco; suscitar o «propiciar» (el título del poemario es significativo al respecto) una nueva conciencia en el lector ante el objeto satirizado.

En la interpretación de la sátira —al igual que en la ironía y en la parodia - hay que tener en cuenta la competencia lectora. Hutcheon se refiere a una triple competencia lingüística, genérica e ideológica. Mientras que las dos primeras juegan un papel fundamental en la ironía y la parodia

18 Véase Northrop FRYE, Anatomy of Criticism, [1957], Princeton University Press, $3^{a}$ ed., 1973 (en concreto, el epígrafe «The Mitos of Winter: Ironie and Satire», pp. 223239); Hodgart Matthew, La sátira, Madrid, Guadarrama, 1969; C. George Peale, «La sátira y sus principios organizadores», Prohemio, IV, 1-2, Abril-Septiembre, 1973, pp. 189-210; Linda HuTCHEON, «Ironie et parodie: stratégie et structure», Poétique, n. ${ }^{\circ} 36$, Novembre 1978, pp. 467-477 y, de la misma autora, «Ironie, satire, parodie. Une approche pragmatique de l'ironie», Poétique, n. ${ }^{\circ}$ 46, Avril 1981, pp. 140-155.

19 Vid. art. cit., p. 200. 
respectivamente, en la sátira, dado su blanco extratextual, cobra relevancia la competencia ideológica: se presume que tiene que haber una cierta homología de valores socio-ideológicos para que el lector interprete y evalúe correctamente la intención impulsiva y final —o sea, actitud e intención- del yo poético ${ }^{20}$. Ahora bien, la intención primaria de la sátira - criticar aspectos reprobables de la sociedad- pierde vigencia en el momento en que el contexto socio-político o la situación que suscita la reprobación y crítica cambia. Por ello José Luis García Martín opina que «Lo que menos interesa hoy de Prosas propicias (...) es quizá lo que tiene de poesía política, de poesía de circunstancias muy ligada a los últimos tiempos de la dictadura» ${ }^{21}$. En cualquier caso, la validez ética y artística de la sátira permanecería.

En «Sátira» las motivaciones extratextuales de la crítica de Luis Felipe Vivanco son de índole sociopolítica, dentro del contexto de los últimos años del franquismo. Tales motivaciones y su oposición a la situación sociopolítica española y a sus poderes fácticos ya estaban presentes en las páginas de su diario, como vimos con anterioridad. La denuncia de la falta de libertad, la censura, la opresión moral y física se observa en la totalidad de las «Sátiras»; el extenso primer párrafo estrófico de su primer poema, «Tercera República», ya es significativo:

La casa está cerrada La llave de la luz está cerrada como perfecta medida de egoísmo Las paredes se ocupan de que nuestra salud no se trate con nadie ni conozca los síntomas de la fiebre de fuera La nariz dosifica su letargo posible su arrobo y su escarmiento Los ojos sólo ejercen su oficio más rentable de gusanos No no somos nosotros Son ellos y no importa Son ellos protegiéndonos es decir enseñándonos sus playas decisivas y vidrieras triunfales Son ellos comulgando bendiciendo y vendiendo predicando y comprando Las mejillas reciben la brisa que no daña La lengua aprende el himno de su felpudo eterno o al menos vitalicio ¿Cómo añorar un mundo de montañismo activo y altura inesperada? Ya no hay nube que finja su invasión femenina no hay servicio gratuito a domicilio ni tentación que valga Los números descubren su cero coma cinco y su diez coma siete por ciento y por cojones $\mathrm{Y}$ así vamos tirando de pequeñas cuestiones y peces de mentira No basta con el llanto de lejos que mantiene nuestros viejos rediles y cosechas Las uñas ya no crecen en los dedos más jóvenes Las manos ya no ocupan lugar entre los pájaros ¿Y esos búhos que silban como hostias consagradas bajo un techo implacable? Son ellos y no importa Pero queremos algo que no suene a esa voz manida y repetida sin entraña inspirada Algo que ya no sepa ni a rancho de victoria ni a orgullo de vencido

\footnotetext{
${ }^{20}$ Frye sostenía que — aparte de una pizca de fantasía - la sátira exige el reconocimiento, por lo menos implícito, de una norma moral, sostén esencial de una actitud militante de cara a la experiencia de la vida: «Satire demands at least a token fantasy, a content which the reader recognizes as grotesque, and at least an implicit moral standard, the latter being essential in a militant attitude to experiencie» (vid. op. cit., p. 224).

${ }^{21}$ José Luis García Martín, «Poesía, I-II», El Cultural, 16 Enero 2002, p. 13.
} 
Ante el impuesto aislamiento físico y moral de la España franquista — «La casa está cerrada...»-, la alienación y enajenación del individuo — «No no somos nosotros...»-, y su frustración — «Cómo añorar un mundo de montañismo activo y altura inesperada?»—, se expresa al final de la estrofa el deseo que todo cambie. Frente a esa voz amordazada por la censura y sustituida por la voz impuesta del poder, de la que se hablaba en esta primera estrofa, en la segunda se alude a la voz de la otra España, la del exilio. Esta es la voz de la libertad, de los sueños, de la dignidad; la voz en la que parece depositarse la esperanza de un futuro mejor, como se sugiere en sus últimos enunciados:

Otra voz y la misma que recoge la tizne y la tortura en la respiración de nuestros hijos Se han reunido los hijos como sueños penúltimos que escapan hacia su propia orilla de pisadas aún libres $\mathrm{Y}$ ahora somos nosotros con traje más gastado pero más exigente Nuestros hijos descubren la educación agreste caminante y profética de esa voz que se adhiere desde su hoja de hierba y el contagio infinito de su barro hacendoso a todos los motivos de un soñar que es política y arrabales despiertos de dignidad humana y tercera República

La voz «caminante y profética» a la que se alude no es otra que la de León Felipe, a quien se dedica el poema, y a cuyo homenaje póstumo celebrado en México asistió Luis Felipe. Como nos recuerda José Ángel Fernández Roca, en tal viaje nuestro poeta también participó en un acto conmemorativo de la Segunda República. Y es que Vivanco pensaba que la España auténtica había sido la republicana, y creía que sólo a ella se volvería con una Tercera República, la misma esperanza por la que luchaba su siempre combativo tío José Bergamín.

Un ingenioso recurso satírico es parodiar formas discursivas previas para adaptarlos a la nueva intención crítica. Hutcheon ha insistido en la frecuente interferencia de lo satírico, lo paródico y lo irónico, y la rareza de su concreción literaria en estado puro. En cuanto a la interferencia entre parodiasátira, una de sus variantes - la sátira paródica - es aquella cuyo blanco es extratextual, pero utiliza la parodia en tanto que dispositivo estructural para realizar su crítica $^{22}$. En Memoria de la Plata Vivanco ya había utilizado la parodia, pero como simple juego intertextual; ahora, el dispositivo paródico se utiliza para satirizar un objetivo extratextual, pero sin que el discurso parodiado sea propiamente objeto de sátira. Lo vemos, por ejemplo, en el poema «Recetas», donde en la parodia de la terminología propia de la posología no sólo se combina el ethos satírico con el paródico, sino que también entra en juego el ethos irónico. La falta de libertad ( «De

${ }^{22}$ En su diferenciación de los tres «ethos», Linda Hutcheon precisa que el blanco del discurso satírico es «extratextual», mientras que el discurso irónico se caracteriza por su carácter intratextual y el paródico por su intertextualidad. 
oxígeno viciado y restricciones de ordenanzas pasivas nacionales y viernes agujereados»), el sistemático engaño del Régimen («De sistema de pompas de jabón y engañosas fachadas programadas de enjuagues sin persona suficiente y alas de maleficio en los telares»), la censura, la represión ..., son los irónicos medicamentos de la Dictadura aplicados al pueblo en irónica dosificación farmacéutica-religiosa; así Vivanco denuncia la alianza Iglesia-Estado en la España del franquismo:

De oxígeno viciado y restricciones de ordenanzas pasivas nacionales y viernes agujereados

d/p un milímetro cínico de Cristo

De sistema de pompas de jabón y engañosas fachadas programadas de enjuagues sin persona suficiente y alas de maleficio en los telares

$$
\begin{aligned}
& d / p \text { un frasco unificado de jarabe } \\
& \text { teológico-agresivo }
\end{aligned}
$$

De secreción de huesos pudibundos y sexo alimentado por placeres caídos en desuso de cuartillas ajenas sancionadas y unánimes aplausos

$$
\begin{gathered}
d / p \text { un tubo complejo de grajeas } \\
y \text { su tupé de alegres navidades }
\end{gathered}
$$

De arañazo final ejecutivo y su cinta adhesiva de cuento que no acaba y frígidas medallas o condecoraciones mutuas y piadosas

$$
\begin{aligned}
& d / p 100 \text { gramos de planteamientos } \\
& \text { místicos y capullos de cardos }
\end{aligned}
$$

Vivanco vuelve a recurrir a la parodia en «Sentencia». Ahora utiliza la estructura, formulismos y tecnicismos — «infrascrita», «causahabiente», «item»...- propios de la forma textual judicial de la sentencia; así expone en las tres primeras estrofas los «considerando» o razones objeto de su sátira - la conculcación de los más esenciales derechos y libertades, y la falta de expectativas ante un futuro mejor-, relaciona en las dos siguientes los «resultando» o hechos comprobados, y concluye con un irónico fallo:

RESULTANDO que en el estado actual de la renuncia se acusan mutuamente de nocivas las particiones hechas y siguen sometidas a un transcurso posesorio ilimitado multiplicando así el innato rencor de las mejillas oponentes que se refugian en los mínimos placeres vegetales de una herencia gastada de antemano

RESULTANDO item que según lo predispuesto en el mandato encomendado a los supuestos albaceas que nacerán al cabo de muchos escenarios y aulas desalojadas que la extracción de un caldo ya difunto como lucro emergente y paridad cesante obtiene prelación sobre toda posible permuta utilitaria de emigrantes y playas

DEBEMOS SENTENCIAR Y SENTENCIAMOS EN JUSTICIA los puntos suspensivos (...) tal vez consustanciales con el mejor desagüe no violento de la mentira diaria y compasiva 
La mordacidad, latente en el marcado estilo irracionalista del discurso poético del anterior poema, es más directa en el único poema en verso regular de la obra, el soneto «La Puntilla». Una vez más se denuncia la virulencia de una Dictadura que alardea de la paz conseguida, pero que, paradójicamente, rezuma rencor y no perdona ni a sus exiliados más conspicuos; por ejemplo, Picasso ${ }^{23}$ :

\footnotetext{
Cuanta más española es nuestra vida y más tradicional nuestro esperpento más larga es la crueldad del planteamiento que nos mantiene en esta paz sufrida.

Nunca falta la sal en nuestra herida, y para asegurarnos el sustento negamos la repulsa y el tormento de tantos años mozos sin salida.

Vamos en procesión marcando el paso militar, y atacamos a Picasso desplegados piadosos en guerrilla.

Somos así: un rencor que no perdona $\mathrm{y}$ un toro que te embiste y empitona y un cristo cachetero. Y la puntilla.
}

La ironía se utiliza en el discurso satírico de «Miedo» para denunciar la represión y censura —en suma, el miedo- que subyace tras la aparente benevolencia de la Dictadura, como se puede observar en las tres siguientes estrofas que seleccionamos:

\section{Qué miedo:}

todo tan bien surtido los servicios los precios todo tan a la mano y al alcance del pollo y el gargajo tan para ti todo todo pasado por la miga de pan y la saliva de gobernantes buenos y sensibles

${ }^{23}$ Vivanco se lamenta muchas veces en su diario del desprecio e indiferencia que la España franquista muestra ante aquellos ilustres artistas exiliados consagrados en el extranjero. La anécdota origen de este soneto es la pertinaz y despreciativa marginación de la que es objeto Picasso que con ocasión, en 1971, de su noventa cumpleaños es homenajeado en el extranjero y, ante todo, por el Estado francés. En este año anota en su diario: « QQué triunfo para la España de Franco, el Sínodo mundial de Obispos, y las actuaciones en él de Tarancón y de Echaren, sosteniendo todo lo contrario - en cuanto a justicia- de lo que está en nuestras Leyes Fundamentales! El $A B C$ todo lo da como triunfo nacional y católico, sin distinciones. En el $Y a$ se hablaba de Neruda como comunista, que es la verdad. Nadie ha hablado de su antifranquismo, ni del de Picasso, al que no se le hace el homenaje nacional!» (op. cit., p. 224). Y dos años después, con motivo de la muerte del pintor, apunta de nuevo: «Porque Picasso, como Machado o León Felipe, es un símbolo universal de antifranquismo, quiere decir: de incompatibilidad con lo que Franco representa como mentira histórico-cultural. Muerto Picasso, queda al frente de la pintura universal, otro español: Joan Miró. Picasso ha muerto, viva Miró. (Y nada de Dalí, que, como Franco, pertenece a la España sucedánea. Qué payaso repugnante.)» (ibidem, p. 230). 


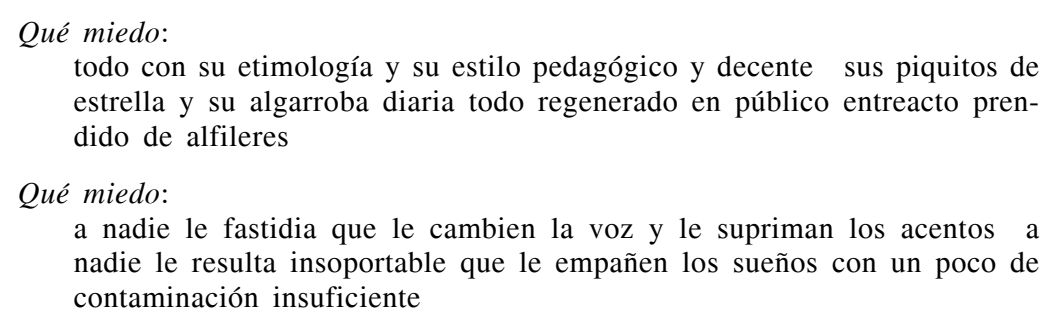

El poema va precedido de una cita que pertenece al «Preludio» de «Parábola», la tercera y última sección de Lecciones para el hijo. En este extenso poema varios hombres vagan maquinalmente, desesperanzados, abúlicos, resignados y pesimistas. Uno de ellos, en su amargura, apunta que su única esperanza es que sus hijos «...mezclados de veras unos con otros, no sean tanta mentira como hemos llegado a ser nosotros»; otro (en evidente pero tácita alusión a la España de los vencedores) achaca su fracaso a no haber matado bastante — porque «los que matan son los que aciertan»- y en el culmen de su desengaño apostilla: «Para eso estamos en el mundo: para hacer daño»; ante esta afirmación, uno de ellos argumenta que «Estamos tan envilecidos por el ruido de las ciudades que no nos atrevemos a escuchar lo que no es ese ruido», mientras que otro súbitamente se levanta e improvisa un mal poema cuyos dos versos iniciales - los que Vivanco recupera como cita del texto que comentamos - rezan: "iQué miedo! / ¡Qué miedo el azul del cielo!» ${ }^{24}$. A la altura de 1961 —-fecha en que se edita Lecciones para el hijo - la censura constreñía la denuncia del poeta a este discurso parabólico. Ya entrada la década de los setenta, y debido también a su más acentuada y decidida actitud crítica ante el Régimen, a Vivanco ya no le sirve el ingenuo discurso parabólico de su anterior obra; su repulsión necesita ahora el peculiar fluir caótico del discurso surrealista para acentuar su denuncia y sátira sobre la situación del país. Vivanco vertebra «Miedo» sobre el mismo planteamiento argumentativo de Lecciones para el hijo, pero prescindiendo de todo enmascaramiento parabólico. Ahora el planteamiento es directamente éste: estamos tan envilecidos y alienados por el miedo que sufrimos que incluso tenemos miedo a lo que no es miedo sino libertad y esperanza. Ese es precisamente el sentido de las estrofas sexta y duodécima del poema, significativamente marcadas en letra cursiva: "Qué miedo: Qué miedo el azul del cielo y la alegría de labios compartidos que se besan y el corazón qué miedo».

En alguna ocasión ya señalé el uso de la intratextualidad (o intertextualidad interna) en Prosas propicias, en cuanto que Vivanco con frecuencia alude o toma citas de sus anteriores obras. El poema que acabo de comentar, «Miedo», es otro caso, pero al mismo texto de referencia de

${ }^{24}$ Vid. Lecciones para el hijo, Madrid, Aguilar, 1961, pp. 211 y ss. 
Lecciones para el hijo alude en otra de sus sátiras, «Hacer daño». De su extensa enumeración reproduzco sólo sus últimos enunciados: «Se afanan se atropellan se pegan entre sí se hacen daño tal vez para hacer daño Retozan son felices ignoran y recuerdan las fechas desagravian $\mathrm{y}$ embisten y se repiten niegan y vuelven a lo mismo se portan bien comprenden descubren la verdad y hasta piden perdón para hacer daño». Ante esta omisión del sujeto gramatical José Ángel Fernández Roca observa que «se nos habla, sin duda de opresión e hipocresía, pero los nombres y las caras ha de ponerlos el lector; la diatriba inteligente evita la obviedad» ${ }^{25}$. El profesor Fernández Roca alude también a otro poema en lo que sucede lo mismo: «Segundo mandamiento». En éste, los que juran en vano, sin razón ni justicia, se enumeran en su tercera estrofa: «Los airados los frágiles los mansos los trigueños los de cal los de arena los señoriales los ingratos los ávidos los que siguen soplando taladrando halagando los cuerdos los insípidos los histriones los suyos Todos juran». El poema no sólo precisa quiénes —los poderes fácticos serviles al régimen-, sino también el «qué» juran — principios, efugios, fundamentos, dogmas...-, el «cómo» — con afición, vocación, ambición, aclimatados, condecorados, importantes, «con las rodillas las manos los testículos»...-, el «para qué» - para encajar, ser obedientes y quedarse, engañarnos, sacarnos los cuartos-, y el «porqué» — por su riqueza, su religión, su dinero, su egoísmo...... La última estrofa condensa la postura crítica y hostil de nuestro autor ante ese «espíritu mostrenco e interesado» -expresión tomada de su diario- de las clases sociales afectas al poder:

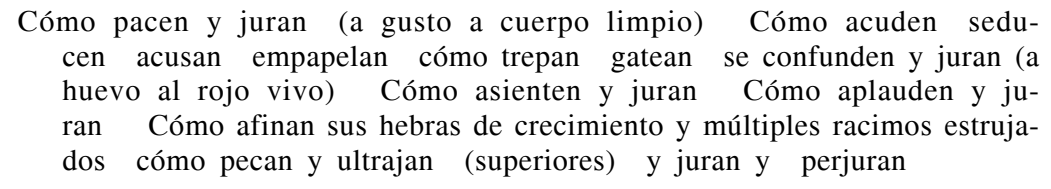

Son las mismas clases sociales cuyos vicios y estulticia representan los López, Sánchez, Fernández o Pérez del poema titulado «Epigramas». Del ingenio y mordacidad que Vivanco despliega en este texto, recurriendo a la degradación y animalización del objeto de su sátira, son buena muestra algunos de sus enunciados poéticos: «Tampoco hay que olvidar tu vaso de elección o indudable servicio de orinar religioso», «Devociones miméticas desprovistas de escrúpulo ensanchan la equidad de tus bolsillos orgullosos de lujo bienpensante», «Prematuro en husmeo y deslealtad tu hociquillo de cerdo no llega a superior categoría de geta francamente censurable», «Marionetas de olé trabuco y sucedáneo títeres de tanguillo desde una voz minúscula te añaden a su baile de candil y piltrafas».

\footnotetext{
${ }^{25}$ Op. cit., pp. 76-77.
} 
En «Descansillo» se recurre al ardid irónico de sugerirnos un edificio - que no es más que España - con tres tipos de viviendas por planta, en clara alusión a los tres sectores ideológicos de la sociedad. Los pisos «derecha» son las denostadas clases pudientes satirizadas en anteriores textos:

Los «derecha» son pisos y pasillos corazas azoteas y cáscaras castizas sumamente indignadas cuando alguien que debiera recibir las migajas se retira y orina bellos y venerables mandamientos patrióticos Sus puestos se dilatan con sabor de mariscos Suplen la numerosa trascendencia del numen con adverbios rituales y cuentas del rosario Falsifican sus propias perversiones Medran entre piscinas y ninfas amañadas Codician y disfrutan herencias y termostatos Dedicados al plácido usufructo de los bienes comunes se reúnen mediocres sin imaginación se arman hasta los dientes sin lecturas y arrastran largas capas de gusanos e incestos $\mathrm{Y}$ pare usté la jaca y qué egoístamente meneamos el rabo satisfechos

Pero la sátira de Vivanco no se detiene ahí, sino que también —aunque en menor medida - apunta a la acomodaticia posición de los «centro», e incluso a los «izquierda»: «Renuncian pordioseros a los pocos aplausos nutritivos para picar más alto Se alejan exigentes y se acercan docentes y afilados Rompen los compromisos y apostatan insomnes como el barco borracho de Rimbaud Así aciertan portátiles y siguen engañándose Se adelantan descubren y no esperan a nadie».

La institución de la Iglesia, como se habrá observado en algunos ejemplos señalados, no se salva de la intención satírica de Luis Felipe Vivanco. En las confesiones anotadas en su Diario vemos cómo el «materialismo católico español», sus obispos y sus pastorales son consideradas «verdades disminuidas». Como ejemplo véase esta entrada de 1960: «iYo no pertenezco al $A B C$, ni a las derechas, ni al catolicismo de los curas de boca negra despotricando desde el púlpito! Hay que ir hacia otra persona. Y hacia Dios, a través de otra persona ${ }^{26}$. La crítica se vuelve especialmente acre y mordaz cuando se refiere al Opus Dei. No hay que olvidar que el sentimiento religioso de Vivanco se forma en conexión con el progresismo católico que antes de la Guerra Civil representó la revista Cruz y Raya, creada y dirigida por su tío José Bergamín. Ya en la posguerra, el Grupo de Escorial -y desde las páginas de la revista que le da nombre- polemizó con los redactores de Arbor, revista ligada al Opus Dei ${ }^{27}$. Pero la actitud crítica ante el Opus no se debe sólo a su catolicismo reaccionario, sino también a la presencia de sus integrantes en los gobiernos franquistas a partir de 1957, a la vez que la Falange queda definitivamente arrinconada

\footnotetext{
${ }^{26}$ Op. cit., p. 152

27 En la reseña de Antología poética aparecida en esta revista no se alude en ningún momento a Prosas propicias, y presumo que no es algo casual (Rafael GómEZ LóPEZEGEA, «Vivanco, Luis Felipe, Antología poética», Arbor, n. ${ }^{\circ}$ 371, Noviembre 1976, pp. 165-166).
} 
por la Dictadura ${ }^{28}$. Las invectivas contra la asociación católica seglar aparecen varias veces en su diario, por lo que no es de extrañar que ahora, en Prosas propicias, le dedique una corrosiva sátira titulada «Negocios» 29 . Veamos como ejemplo su tercera y última estrofa:

Obra de Dios rentable al $100 \%$ : fieles y rasurados perseguís la exclusiva de un tic-tac simoníaco y por todo lo alto «club» de «golf» y urbanismo Levantáis testimonios pañales y eufemismos contra un cristal limpísimo de pelvis femenina y asistís a reuniones presididas a dedo duchas en maniobras de eficacia y tutela entre indefensos Vuestra letra se arrastra sin estilo parodiando los textos de un porvenir auténtico Vuestras siglas pronuncian la oración y celebran las fiestas esotéricas de no estar con el pueblo Así admitís el rango de un desfile en olor de felices coyunturas y convocáis difuntos privilegios que aceptan pulimento de cinismo infalible carismático

En el poema final de esta segunda parte de Prosas propicias - el titulado «No soy digno»— el sujeto poético condensa su personal posición ante la situación sociopolítica descrita y satirizada en todos los textos anteriores. Si para amigos y familiares no es merecedor de esa disminuida España que le ha tocado vivir, para otros, los partidarios y comparsas del Régimen — «los bien olientes de inercia y adherencia», «los bien sintientes de rienda y de bocado»—, tampoco es digno, por su oposición, de esa supuesta España de orden, paz y desarrollo. En cualquier caso, el yo poético no es sospechoso de haberse beneficiado de esta última, como irónicamente se expresa en la penúltima estrofa del poema — «No desde luego que no soy digno No debería estar aprovechándome de esta holgura y exceso de tanto bienestar y tanta melodía de viajes ajenos de tanto suministro y contaminación donde mojar las puntas de los dedos con que nos santiguamos». La ironía aflora especialmente amarga y con un cierto sentimiento de autoinculpación en su última estrofa:

Tal vez sólo soy digno de arroyo casi mágico que dispersa sus aguas para desconectarlas de un botón que se aprieta y establecer con ellas su ociosidad de ensueños en algunos senderos apartados de muy poca importancia

${ }^{28}$ Para estos aspectos de índole política véase Stanley PAYNe, Historia del fascismo español, París, Ruedo Ibérico, 1969, pp. 212 y ss.

${ }_{29}$ Estas son dos de las anotaciones críticas de su Diario, la primera de 1956 y la segunda de 1962: «Todo lo han invadido Opus y Falange, dos maneras oportunistas de no ser como Dios manda (ni las obras ni los obispos de fuera de España, con el Papa a la cabeza tampoco)»; «Los comentarios de la prensa española al Concilio, a pesar de toda su buena intención, son muy inferiores al Concilio. ¿Estamos, en España, a la altura de él? Yo creo que no (...) Hoy más que nunca, con Ministro del Opus en el poder. Con el poder del Opus, parcial y estricto. ¿Qué lástima de ocasiones de ser europeo, católico hacia el futuro, etc.! Y todo por la maldición del partido único, de la falta de libertad en la vida pública y social» (1962). 
6. «Prosas de amistad», la tercera y última sección de Prosas propicias, agrupa una serie de poemas dedicados a autores amigos o admirados (casi siempre poetas), con motivo de una obra recién publicada de estos o bien como homenaje debido a distintas circunstancias (aniversario, necrológica, etc.) Estas prosas de amistad conforman una sutil urdimbre donde la experiencia vital —social e íntima - de Luis Felipe Vivanco se integra y entra en dialéctica con los parámetros clave de la obra - concreta o global- del autor celebrado. Como ya veíamos en sus «Prosas líricas», también ahora vemos cómo la actitud crítica y la temática social específica de los poemas de la segunda sección, «Sátira», afloran en las composiciones de esta tercera.

En varios textos simplemente se aplaude el compromiso social del poeta homenajeado. En «Cantiga hacia mañana» se ensalza la actitud crítica de Celso Emilio Ferreiro y su poesía en gallego (y en especial la de Longa noite de pedra) cívica y solidaria, como claramente se observa en sus dos últimas estrofas:

Celso Emilio tu sonda perseguida bucea en su derroche de noches clandestinas y apáticas migajas de caldo y catecismo para avivar las brasas $\mathrm{y}$ modelar un barro de dignidad unánime y creada

Celso Emilio Ferreiro no apruebo la violencia con que los pazos más fanáticos llegaron a humillarte malparado de hambre y cementerio pero apruebo la tuya que suena en son de amigo que devuelve su curso celeste a la mañana

Lo mismo sucede en los poemas «Carta-prólogo» o «Mutismo de Pablo». En el primero Vivanco exhorta al novelista y poeta segoviano Ramón Ayerra a persistir en su poesía de denuncia y de solidaridad con los más humildes. En «Mutismo de Pablo», sus seis primeras estrofas —con su irónica anáfora «qué bien»- son un reiterado lamento por la voz comprometida de Neruda, ahora silenciada por su muerte y por el advenimiento de la dictadura: «Qué bien que ya no cantas qué bien que ya no hablas qué bien que ya no rabian en tu voz colectiva constelaciones y olas vegetaciones ríos minerales y hombres», "Qué bien Pablo qué bien que ya estás mudo y quieto ya estás eternizado ya no incordias cadáver y al son de tu mutismo se decretan tres días deshonestos de luto nacional».

En consonancia con la actitud de compromiso y la poesía cívico-social de muchos de los autores que celebra en sus «Prosas de amistad», la palabra poética de Luis Felipe Vivanco también denuncia los males que aquejan a la sociedad del momento. Como acabamos de ver, en «Mutismo de Pablo» denuncia el golpe militar y la consiguiente muerte de Salvador Allende, al que compara con su antepasado José Manuel Balmaceda, quien se suicidó tras ser derrocado por un ejército y una oligarquía plutocrática 
opuesta a sus planes liberales: «Te has muerto cuando Chile derrama sobre el mundo la estatura moral y el prestigio del nombre de un nuevo Balmaceda y presunto suicida asesinado».

Ahora bien, en «Prosas de amistad» la crítica sociopolítica se reduce básicamente al contexto español. En «Américo en España»-y siguiendo la intención y pautas de la obra de Américo Castro La realidad histórica de España-, se indaga en nuestro pasado para dejar constancia tanto de nuestra esencia como de nuestros errores históricos. Vivanco valora la riqueza de nuestro legado literario y la impronta en él de otras culturas (es clara la referencia a la obra de Ibh Hazm de Córdoba): «Me gustan las palomas y los romances fronterizos me gustan los fragmentos de una espera de amor que agota sus estrellas y no sigue enredando y malgastando su agudeza de ingenio // Me gustan los almiares me gustan los buscones y sus líricas suelas desgastadas pero me gusta más ese ojo irreal de Garcilaso que derrama sus lágrimas fingidas sobre un tierno paisaje de estrofas verdaderas». Sin embargo, deplora las lacras de nuestro pasado apuntadas por el conocido historiador: la fatua hidalguía, el marasmo intelectual, la persecución xenófoba... Sirvan como ejemplo de la incisiva crítica de Vivanco estas dos estrofas: «Nuestras cuerdas vocales tienen una triple mordaza de lujuria mental y hay un triple silencio de apetito y bozal analfabeto como un lienzo indefenso de libres pinceladas y bufones penúltimos que añoran otras épocas», «Oh España eres liviana superficie jurídica pero pluscuamperfecto volumen policíaco en niños acusicas de semen y bautizo y ancianos venerables a fuerza de espiar y sobrevalorar las flaquezas del prójimo». En «Palinodia blanca» (comentario al libro Blanco Spirituals, de Félix Grande) Vivanco vuelve a incidir irónicamente en nuestro vacuo orgullo de pueblo colonizador y evangelizador — «Somos blancos y enseñamos lo dientes de espíritu con Pablo el navegante....», «Que no nos tosa nadie porque hemos amarrado todos los litorales sobre la piel del mapa»-, aunque en este poema la denuncia parece hacerse extensible a la falaz superioridad de la raza blanca: «Somos blancos y escépticos e históricos religiosos y múltiples dominantes y ahítos químicos carniceros y carteros pero siempre al acecho y cazadores».

Salvo estas dos excepciones, la crítica se centra en la situación social y política del presente. Las reiteradas alusiones a la violencia, las injusticias, el miedo y la desilusión que se observan en estas «prosas de amistad» se refieren a la sociedad española atenazada por una dictadura, que, a la vez, condena al exilio -obligado o voluntario- a sus disidentes. En «Quimeras de la Serrota» Vivanco recuerda el exilio de su amigo José Herrera Petere — «Hace ya mucho tiempo que en el túnel o vientre del exilio no verén...»-; al de Serrano Plaja se alude en «La condición canina»; y en «Sátira» rememora las razones que arrojaron a Valverde al exilio tras ser desposeído de su cátedra por motivos políticos: «No abandono la mentira 
presente/sino las ilusiones de un futuro precario. No huyo de mí mismo ni de mis soledades / sino del planteamiento de un cotarro accesible / sólo para unos pocos».

En su denuncia, Vivanco recurre a su voz poética más mordaz y corrosiva, como se puede comprobar en las siguientes dos estrofas de «Fernando y sus recuerdos», en las que se refiere a Franco — degradado a la condición de reptil escondido en su palacio de El Pardo- y demás corifeos de la Dictadura:

Recuerdos nacionales de tranquillo y de trágala Reptil subpicaresco que llega hasta las tapias de su pardo pelaje Polígonos ambiguos y lecciones anfibias en motores de aumento policíaco Fósiles fotocopias de autarquía y enfermizos prudentes escenarios de represalias físicas Posaderas patrióticas posando en ovaciones y sangre que ilumina los hilos del telégrafo

Recuerdos nacionales de acrobacia y sucesos pudibundos cabestros de cinismo y protocolo en una voz pultácea como un disco rayado y paralítico Cangrejos sanguijuelas victoriosas y cáscaras que fingen lo que nunca ha pasado Ceremonias sacrílegas en captura capciosa de conciencias sumisas de antemano Máquinas de acuñar y envilecer sin arrepentimiento y sangre que adivina lo que seremos al cabo de otros tantos siglos

Si en este poema - dado el título y características de la obra celebrada (Materia de recuerdos recoge poemas escritos por el arquitecto Fernando Chueca entre 1937 y 1947) - se alude a la primera década de la dictadura, la situación social y política —en cuanto a la privación de las más esenciales libertades - se mantiene inalterable tres décadas después, como se denuncia en «Insomnio 73», poema homenaje a Hijos de la ira de Dámaso Alonso:

Han seguido creciendo uniformados los cadáveres Han seguido pudriéndose conformes victoriosos difuntos agresivos (Siempre conforme y según las últimas estadísticas)

Han crecido las sillas los armarios las camas —oh larvas de Ionesco- han crecido las mentes propagadas que embisten y los rinocerontes

Ha crecido Madrid hasta el delirio de los cerebros electrónicos hasta la información bien escogida que aplica su candado a las escuelas ${ }^{30}$

Esa es la realidad social y moral de España, la verdadera realidad que subyace tras la fachada propagandística de un creciente desarrollo del país. Se observa en «Calle de Melchor Fernández Almagro» cuando Vivanco

${ }^{30}$ En la segunda de estas estrofas hay referencias a dos obras de Eugène Ionesco, con lo que Vivanco enfatiza dos dimensiones de su denuncia: la deshumanización de la sociedad -idea motriz en Las sillas - y la degradación del ser humano, reducido a simple bestia bajo los regímenes totalitarios -idea desarrollada en forma de parábola en El rinoceronte-. 
alude irónicamente a la conocida política de viviendas sociales emprendida por el INV (Instituto Nacional de la Vivienda) — «Alégrate y recibe la lluvia natural y los humos que anuncian tu póstuma ascensión hacia el progreso saturados de indígena protección oficial pero a escala europea»-; o en «Carta-prólogo», donde Vivanco se refiere a los embalses inaugurados en tiempos del Régimen, a la vez que denuncia la creciente corruptela que tal desarrollo genera: «Todos sabemos lo que nos desprestigia deteriora y descubre lo que nos enmudece porque no acontece Presa dique o tijeras sin pregunta Conservas infectadas sobre la cuerda floja sin respuesta Suburbios y manubrios que siguen aprendidos de memoria Tordesillas Chipionas Crevillentes Cotillos Covarrubias y otros muchos destajos estrofas o patíbulos que pueden prescindir de su escenario humano fielmente incorporados a los ardides de la ambición al uso».

Tras la realidad tergiversada que los medios de comunicación en manos del Régimen ofrecen — «hojas turbias que administran lejanos monigotes»—, está la otra verdadera realidad que se oculta, pero todo el mundo conoce: «Sabemos lo que todos no escribimos ni amamos ni casi articulamos con nuestras firmas óseas de pesca y desacato Sabemos lo que todos dejamos de evitar de honrar de fornicar y de inventar yacientes Lo que todos pensamos adyacentes repetimos sobrantes sobamos y ensuciamos y hacemos que olvidamos: ventanas desarmadas entierran sus desmayos en visiones locales de adioses que chorrean sus pústulas patrióticas a la sombra del ídolo». A la férrea censura se alude irónicamente en otras varias ocasiones: «Hoy por hoy nos manchamos con su ayuda oficial de periodismo sus falsos aforismos y sus falsos tranvías que censuran los pasos pecadores que dio la comparsita («Respuesta inicial»); «¿Por qué no vigilar censurar y vetar las yemas insolentes de los árboles?»-irónica interrogante presente en «Insomnio 73»- En boca de José M. ${ }^{a}$ Valverde (en el poema, ya citado, que le dedica) Vivanco pone estas amargas reflexiones: «Bajo el rostro y la máscara / del periódico, leo la verdad perseguida / porque nos hace libres. Y ese miedo a ser libres / se instala en mayoría, ya a gusto para siempre. // ¿Hay que encogerse de hombros y seguir prosperando / con la mala conciencia satisfecha en su vómito? / ¿Hay que aceptar la línea divisoria trazada /desde arriba, entre algunos productos europeos / aptos para menores —es decir, españoles- / y el resto de alimentos indigestos no aptos?».

En algunas de estas prosas vemos aflorar un cierto sentimiento de culpa por dos motivos. Por un lado, en «Epístola de ayer» — dedicada a Dionisio Ridruejo- intuimos un cierto descargo de conciencia por su colaboración en el pasado con el régimen que ahora denuncian: «Cultivamos ambiguos disidentes la propiedad privada del paraguas y hacemos el amor con nuestra penitencia de sección femenina». Por otro, parece lamentarse por no implicarse más en la lucha contra la dictadura, como observamos 
en «La condición canina»; en este poema Vivanco se compara con su amigo en el exilio, Arturo Serrano Plaja — «Pero tú no te hartas de estar fuera Y muerdes Yo no me harto de estar dentro y no muerdo»- y concluye: «Yo no puedo husmear medroso a la intemperie no puedo echar de menos sino acatar las órdenes y aceptar que la mano que acaricia mi lomo y me tira de las orejas no es la mano de Dios iqué mas quisiera!». No es de extrañar, por tanto, que admire y alabe la persistente actitud crítica de su tío José Bergamín (en el poema «Tercer oído»): «Tú agitas como un triunfo tu fantasma impalpable y vulnerable Tú no estás permitido no estás arrinconado ni arruinado y escuchas las rendijas iniciales de tu tercer oído desde el rescoldo ceniciento de tu rapsodia triste».

Es evidente el pesimismo de Vivanco cuando reflexiona sobre nuestro devenir histórico y la situación política del momento - la dictadura franquista- No obstante, al igual que Américo Castro apuntaba en el prólogo de su mencionada obra que ésta aspiraba a ser «constructiva y alentadora», nuestro poeta, animado por su lectura, deja también abierto un frágil resquicio a la esperanza. Se observa en estos versos del poema que le dedica - «Debemos ser triunfales de esfuerzo y despilfarro de ortigas que acarician y cardos que adoctrinan y oculto manantial goteando en sordina su porvenir filtrado sin poder procrear todo lo que quisiera»-, apreciación que remacha en su estrofa final: «El patriotismo no es mi fuerte pero tu libro Américo me hace flotar ingrávido en ese edén perdido pero recuperable que es mi ser y asidero conspicuo de español». Por esto mismo, en el poema «Aquel verano (en los 80 años de Jorge Guillén)» - y al igual que sucede en la obra de éste a partir de Clamor-, exhorta a los poetas para que, dentro de sus exiguas posibilidades, denuncien la situación:

La poesía cambia de costado y sus horas fallidas se esconden en el pálido abrazo del espejo

Si estábamos a punto y admitidos si todos respirábamos acordes nuestra misión apenas empezada

Si el pan hecho mendrugo devoraba su inercia y ocupaba una estrella bienhechora de escándalo y asueto

Pronto un clamor histórico de familias heridas situó sus guirnaldas sobre el pecho del mar que olvida y flota

No esperéis otro otoño no acuséis a las nubes que suben doloridas o al último vencejo

Las firmas excluidas los jueces como acólitos y los muchos expertos rebosan las exiguas proporciones de pacientes poetas

A falta de las páginas mejores sumemos los excesos de subsuelos y mentes negativas exportando sus huesos

Hay un lápiz estéril que patrulla los ojos y tinteros volcados sobre un botín o jaula de horizonte 
Hay pérdidas afines de carne y de relámpago de hospital y matute de madrugada y mano que acaricia

Porque ninguna otra violencia o desmesura puede aliviar los hombros exclusivos del culpable

$\mathrm{Y}$ en la sesión continua de sangre puntualmente derramada sopla el gallego insano

Esta prosa es un ejemplo claro de la importante función del paratexto y de la intertextualidad en Prosas propicias de Vivanco ${ }^{31}$. Este poema lleva como epígrafe una cita de la oda «A Felipe Ruiz» de Fray Luis de León - « ¿No ves cuando acontece / turbarse el aire todo en el verano? / El día se ennegrece, / sopla el gallego insano...»-, comienzo de la descripción de la tempestad que el fraile agustino pone como muestra del poder de Dios en el gobierno del cosmos. Con irónica sutileza, pero con acre mordacidad, Vivanco concluye su poema haciendo que el viento enfurecido del texto luisiano se convierta a ojos del lector en la figura del dictador Franco venido, como el viento, del noroeste.

7. Aunque ya muerto el dictador, en 1976 - fecha de publicación de Prosas propicias - el entramado del franquismo seguía operante en un país que se mantenía expectante ante su futuro; la denuncia socio-política del poemario no estaba, pues, desfasada, como tampoco lo estaba formalmente. Ya se señaló que Vivanco no compartía los presupuestos del realismosocial de los cincuenta; por el contrario, su posición estética era muy semejante a la poesía crítica que cultivaban los componentes de la llamada Generación del 50. En palabras de Carlos Bousoño, «En la poesía crítica, al revés de lo que sucedía en la poesía social, que procuraba esconder todo lo posible la persona como tal del autor, aparece ésta sin paliaciones ni disimulos. La concreción autobiográfica del contemplador, e incluso la consiguiente autoacusación, se hace, por tanto decisiva ${ }^{32}$. Por otro lado, su escritura experimental y surrealista no era disonante con la nueva estética novísima que en aquellos momentos se imponía. Sin embargo, Prosas propicias pasó desapercibido, sin que se le prestase la atención crítica que un poemario tan denso temática (y no sólo por su crítica social) y estilísticamente merecía. Tal olvido posiblemente sólo se pueda explicar por la misma causa extraliteraria que marcó a sus compañeros de grupo. Manuel Vázquez Montalbán ya nos apercibió sobre ello cuando en 1968 se le preguntaba por los escritores que más habían influido en la poesía del momento y en él particularmente: «Lamentablemente, la política nos ha hecho

\footnotetext{
${ }^{31}$ Estos aspectos se estudian en mi artículo «Elementos paratextuales en Prosas propicias, de Luis Felipe Vivanco», de próxima aparición en RILCE.

32 Vid. «Prólogo» a Francisco Brines, Poesía (1960-1971), Barcelona, Plaza \& Janés, 1974, p. 32.
} 
infravalorar, me refiero a las gentes de mi atmósfera cultural, a poetas tan considerables como Panero, Valverde, Vivanco o ese extraordinario autor de un libro magistral: La casa encendida de Luis Rosales» ${ }^{33}$.

${ }^{33}$ Vid. José BATLló, Antología de la nueva poesía española [1968], $3{ }^{\text {a }}$ ed., Barcelona, Lumen, 1977, p. 342

RLit, 2006, enero-junio, vol. LXVIII, n. ${ }^{\circ} 135,173-198$, ISSN: 0034-849 